\title{
Epinephrine's effects on cerebrovascular and systemic hemodynamics during cardiopulmonary resuscitation: metabolic changes may limit the persistence of the effect
}

\author{
Romain Jouffroy ${ }^{1,2}$ (D) and Benoît Vivien ${ }^{3,4^{*}}$
}

To the Editor,

Mavroudis et al. [1] recently reported that, in a swine model of pediatric in-hospital cardiac arrest, epinephrine increases cerebral blood flow (CBF) and cerebral tissue oxygenation, its effects waning after the third epinephrine dose. The authors should be congratulated for this study concerning one of the main medications used for cardiopulmonary resuscitation (CPR) whose safety and efficacy remain under debate $[2,3]$. Nevertheless, we believed that some points of their study should be pointed out. First, it seems surprising to use epinephrine as a first-line treatment for a shockable cardiac arrest, for which defibrillation is the recommended first-line treatment [2]. Second, the animal model used, i.e., a swine model of asphyxia associated cardiac arrest, resulting in acidosis and hypoxemia, may partly explain the lack of epinephrine efficacy on CBF and cerebral tissue oxygenation observed after the third dose (see additional File 2) because of the negative effects of hypoxemia and acidosis to the response to sympathomimetic agents [4]. Acidosis

This comment refers to the article available at https://doi.org/10.1186/s1305 4-020-03297-4.

*Correspondence: benoit.vivien@aphp.fr

${ }^{3}$ SAMU de Paris, Service d'Anesthésie-Réanimation, Hôpital Universitaire

Necker - Enfants Malades, APHP. Centre, Assistance Publique - Hôpitaux de Paris, Paris, France

Full list of author information is available at the end of the article and hypoxemia impair the vascular alpha-1-sympathomimetic receptor response and limit the epinephrine efficacy on blood pressure and coronary perfusion increases [4]. Mavroudis et al. [1] results suggest that the previously reported deleterious effects of cumulative epinephrine doses $[2,3]$ are probably not related to epinephrine itself but to its lack of efficacy due to the underlying metabolic alterations.

In conclusion, we fully agree with Mavroudis et al. [1], that, despite the exact mechanisms of epinephrine's effects on CBF and cerebral oxygenation, CPR methods, including epinephrine administration, aim to maintain $\mathrm{CBF}$ in order to limit cerebral hypoperfusion and neurologic injury. Moreover, even if CPR methods allow to maintain CBF, pending cardiac arrest etiological treatment, short and long-term survival increase requires a true bundle of care, including, CPR methods and cerebral protection, implemented complementarily to the chain of survival [5].

\section{Authors' response}

Constantine D. Mavroudis, Ryan W. Morgan, Morgan A. Berg and Todd J. Kilbaugh

We appreciate the insightful remarks of Drs. Jouffroy and Vivien regarding our laboratory study of the cerebral hemodynamic response to epinephrine during cardiopulmonary resuscitation [1]. We wish to respond to the authors' commentary regarding the impact of the cardiac arrest model utilized on the study's findings. original author(s) and the source, provide a link to the Creative Commons licence, and indicate if changes were made. The images or other third party material in this article are included in the article's Creative Commons licence, unless indicated otherwise in a credit line to the material. If material is not included in the article's Creative Commons licence and your intended use is not permitted by statutory regulation or exceeds the permitted use, you will need to obtain permission directly from the copyright holder. To view a copy of this licence, visit http://creativecommons.org/licenses/by/4.0/. The Creative Commons Public Domain Dedication waiver (http://creativeco mmons.org/publicdomain/zero/1.0/) applies to the data made available in this article, unless otherwise stated in a credit line to the data. 
Our study utilized an asphyxia-associated model of cardiac arrest because a substantial proportion of in-hospital cardiac arrests in children and adults occur in the setting of respiratory failure. After seven minutes of asphyxia, ventricular fibrillation (VF) was electrically induced. This was done principally for the purpose of ensuring a consistent minimum duration of cardiac arrest in which to study intra-arrest physiology (i.e., animals do not regain spontaneous circulation until defibrillation is provided at a set timepoint). In some laboratory models, CPR is provided to animals with asphyxia-associated pulseless electrical activity (PEA) or asystole. This offers clinical relevance but is frequently followed by prompt ROSC, which precludes extensive study of intra-arrest physiology. Drs. Jouffroy and Vivien are correct in their assertion that timely defibrillation is of paramount importance during a VF arrest and should not be delayed in order to administer epinephrine. However, in this established model of cardiac arrest, allowing VF to continue untreated for ten minutes prevented changes in underlying rhythm and spontaneous circulation, thus reducing confounding in our analysis of the effects of epinephrine on cerebral hemodynamics.

We agree with the hypothesis that metabolic derangements during cardiac arrest likely play an important role in the observation that epinephrine's cerebral hemodynamic effects diminish later in the course of CPR. The effects of acidosis on the efficacy of vasopressors and inotropes, especially at the extremes of cardiovascular physiology, is an area of ongoing research. In a 2013 study by Vidal et al, the vasoactive effects of epinephrine and norepinephrine were not negatively affected after exposing ex vivo human mammary artery to moderate $(\mathrm{pH} 7.2)$ and even severe ( $\mathrm{pH}$ 6.8-7.0) acidosis [6]. The deleterious cardiac effects of severe acidosis are well known, and the potential for superimposed acquired pulmonary hypertension and right heart failure during prolonged periods of acidosis and cardiopulmonary resuscitation may certainly confound any potential benefit that epinephrine could have during prolonged resuscitation. The further effects that the myriad physiologic perturbations associated with cardiac arrest and subsequent resuscitation might have on the incompletely developed (and poorly understood) cerebral autoregulatory mechanisms in juvenile animals and humans are an important additional concern, and require further research.

It is important to note that while the asphyxial model studied does in fact lead to acidosis and severe hypoxemia, our previous work with this model demonstrated that after six minutes of CPR, hypoxemia was resolved, $\mathrm{PaCO} 2$ was nearly normalized, and $\mathrm{pH}$ was higher than at CPR onset [7]. Thus, we are not convinced that epinephrine's ineffectiveness later in CPR was a function of our asphyxial model, but rather that it may be indicative of metabolic and physiologic changes that occur with prolonged CPR in general. Further dedicated study to elucidate these mechanisms may allow us to target them and optimize cerebral hemodynamics even during prolonged resuscitation.

\author{
Acknowledgements \\ None. \\ Authors' contributions \\ BV and RJ wrote the manuscript. All authors read and approved the final \\ manuscript.

\section{Funding} \\ None.
}

Ethics approval and consent to participate

Not applicable.

Consent for publication

Not applicable.

Availability of data and material

Not applicable.

\section{Competing interests}

Authors have no conflicts of interest to declare.

\section{Author details}

1 Service de Médecine Intensive Réanimation, Hôpital Universitaire Ambroise Paré, APHP. Université Paris Saclay, Assistance Publique - Hôpitaux de Paris, Boulogne Billancourt, France. ${ }^{2}$ Université de Versailles Saint Quentin, Versailles, France. ${ }^{3}$ SAMU de Paris, Service d'Anesthésie-Réanimation, Hôpital Universitaire Necker - Enfants Malades, APHP. Centre, Assistance Publique - Hôpitaux de Paris, Paris, France. ${ }^{4}$ Université de Paris, Paris, France.

Received: 23 October 2020 Accepted: 9 November 2020

Published online: 16 February 2021

References

1. Mavroudis CD, Ko TS, Morgan RW, et al. Epinephrine's effects on cerebrovascular and systemic hemodynamics during cardiopulmonary resuscitation. Crit Care. 2020;24(1):583. https://doi.org/10.1186/s13054-020-03297 $-4$

2. Panchal AR, Berg KM, Hirsch KG, Kudenchuk PJ, Del Rios M, Cabanas JG, et al. 2019 American heart association focused update on advanced cardiovascular life support: use of advanced airways, vasopressors, and extracorporeal cardiopulmonary resuscitation during cardiac arrest: an update to the American heart association guidelines for cardiopulmonary resuscitation and emergency cardiovascular care. Circulation. 2019;140(24):e881-94.

3. Perkins GD, Ji C, Deakin CD, Quinn T, Nolan JP, Scomparin C, et al. A randomized trial of epinephrine in out-of-hospital cardiac arrest. N Engl J Med. 2018;23(379):711-21.

4. Kaplan JA, Guffin AV, Yin A. The effects of metabolic acidosis and alkalosis on the response to sympathomimetic drugs in dogs. J Cardiothorac Anesth. 1988;2(4):481-7.

5. Jouffroy R, Vivien B. Bundle of care taking into account time to improve long-term outcome after cardiac arrest. Crit Care. 2018;22(1):192.

6. Vidal C, Grassin-Delyle S, Devillier P, Naline E, Lansac E, Ménasché P, Faisy C. Effect of severe acidosis on vasoactive effects of epinephrine and norepinephrine in human distal mammary artery. J Thorac Cardiovasc Surg. 2014;147(5):1698-705. https://doi.org/10.1016/j.jtcvs.2013.11.013. 
7. Morgan RW, Kilbaugh TJ, Shoap W, et al. A hemodynamic-directed approach to pediatric cardiopulmonary resuscitation (HD-CPR) improves survival. Resuscitation. 2017;111:41-47. https://doi.org/10.1016/j.resus citation.2016.11.018.

\section{Publisher's Note}

Springer Nature remains neutral with regard to jurisdictional claims in published maps and institutional affiliations.
Ready to submit your research? Choose BMC and benefit from:

- fast, convenient online submission

- thorough peer review by experienced researchers in your field

- rapid publication on acceptance

- support for research data, including large and complex data types

- gold Open Access which fosters wider collaboration and increased citations

- maximum visibility for your research: over 100M website views per year

At BMC, research is always in progress.

Learn more biomedcentral.com/submissions 